\title{
Credit Rating in China's Bond Market: Evidence from Short-Term Financing Bonds
}

\author{
Song Zhu \\ Business School, Beijing Normal University, Beijing, China \\ Email: zhusong@bnu.edu.cn \\ Received December 17, 2012; revised January 17, 2013; accepted February 16, 2013
}

\begin{abstract}
In recent years, the Chinese government has highly emphasized the development of bond market, which plays an important role during the development of macro-economy and finance sector in China, especially on some crucial steps concerning national economy and the people's livelihood, as well as reforms in banking industry and the financial innovations. However, the bond market is smaller compared with its counterparts abroad, and its structure is much simpler. To promote the development of bond market, credit rating is very important, which has been hotly discussed during and after the recent financial crisis. This paper discusses the credit rating of bond in China, particularly the short-term financing bonds (STFBs). Our results reveal that almost all credit ratings for STFBs are A-1, the highest rating, which cannot provide investors with effective information, thus being consistent with some critical voices. However, the credit ratings for issuing firms exhibit significant difference so that they are reliable benchmarks for bond investors, and credit ratings indeed reflect the risk of issuing firms in China. Our paper provides more information for foreign and domestic investors about the bond market and the credit rating in China, and gives answer to the question about efficiency of bond rating in China. We provide some evidence for the reliability of rating in China though it is still in its early stage.
\end{abstract}

Keywords: Bond Market; Credit Rating; Short-Term Financing Bond

\section{Introduction}

Bank loans, bonds and equity financing are three important financing channels all over the world. In recent decades, many countries, including China, have taken great steps to promote the development of their bond markets. However, nowadays in China, financing still relies heavily on bank loans, while the direct financing from bond and equity market remains small since the stock market is in its early stage and the bond market is even smaller. For example, the bank loans, stock market value and bonds value at the end of 2006 in China is 22.5 trillion, 10.6 trillion and 8.8 trillion, which is $1.08 \%$, $0.50 \%$ and $0.42 \%$ compared with the GDP (see [1]). In recent years, the Chinese government has highly emphasized the development of bond market. During the national finance conference in January 2007, explicit plans on bond market development was made. And during the 17th National People's Congress of the Communist Party of China, it was also pointed out to improve the direct financing and develop all kinds of financing market since it is crucial to promote the development of the bond market for the financing system reform and the stable economic growth.

Credit rating is very important to the development of bond market, which has been hotly discussed during and after the recent financial crisis. Although the three famous credit rating institutions, Standard \& Poor, Moody and Fitch, have been heavily criticized by the market for their independence and fairness on firms' rating during this crisis, their ratings still greatly influence the world's economy. On April 27, 2010, long-term sovereign credit rating of Greece government was downgraded from $\mathrm{BBB}+$ to $\mathrm{BB}+$, and the short-term rating was downgraded from $\mathrm{A}-2$ to $\mathrm{B}$. The negative rating further shocked Greece economy and the global securities markets. In order to save the market and global economy, US President Obama signed the "Dodd-Frank Wall Street Reform and Consumer Protection Act" in July 2010, which imposed more restrictions and responsibilities for the credit rating institutions, showing how important credit rating is to the healthy development of the market and economy. Recently, Dagong Global Credit Rating Co., one of the biggest credit rating institutions in China, failed to obtain the qualification for rating in U.S. by SEC (Securities Exchange Committee) due to the crosscountry regulation. Is the credit rating in China not equivalent with that abroad? Or do the ratings in China fail to reflect the risk of firms or bonds? Some critical voices propose that credit rating in China can hardly reflect the risk and is less related with bond characteris- 
tics and firm fundamentals (see [2,3]). However, less is known for foreign investors and scholars, even for investors in China. Since the credit rating is crucial in bond issuance and constrains the development of the bond market, whether ratings on bonds in China are efficient or not is an important and interesting question to be answered.

\section{Bond Market in China}

\subsection{The Development}

The bond market in China has developed since 1981 when the government bond was firstly issued. Now it consists of three sub-markets, the Interbank Market, Exchange Market and Over the Counter (OTC) Market. Among them the interbank market is the main body, and its size is about $90 \%$ of the whole bond market.

There are several different bonds in the market in China, including the government bond (GB), central bank bond ( $\mathrm{CBB}$ ), financial bond (FinB), corporate bond (CB), short-term financing bond (STFB), asset-backed security (ABS), note bonds (NB) and foreign bond $(\mathrm{ForB})^{1}$. Figure 1 shows the total number of bonds issued during 1997 to 2010 in China, and Table 1 shows the details for each category, all indicating a rapid growth.

In 1997, there were only four bonds issued in China's bond market and they were categorized into three kinds, while in 1998 though the number was tripled, there were only government bond (GB) and financial bond (FinB). During 1999 to 2001 there were still only government bond (GB), central bank bond (CBB) and financial bond (FinB). Until 2005, the short-term financing bond (STFB), asset-backed security (ABS) and foreign bond (ForB) came into being.

Figure 2 shows the amount of bonds issued (issuing size in trillion RMB) in China from 1997 to 2010, and Table 2 further shows the detailed issuing size. The size of the bond market rapidly grew after 2001 at the speed of over 50\%. Although in 2008 the issuing size dropped due to the globe financial crisis, the market continued to go upwards afterwards.

Among those bonds issued, the rapid growth is mainly due to the increase of central bank bond (CBB), government bond $(\mathrm{GB})$, financial bond (FinB), corporate bond (CB) and short-term financing bond (STFB).

The bond market plays an important role during the development of macro-economy and finance sector in China, especially on some crucial steps concerning na-

\footnotetext{
${ }^{1}$ Different bonds of bond market in China are regulated by different authorities. Specifically, the ordinary firm bond is authorized by National Development and Reform Commission; the corporate bond is authorized by Chinese Securities Regulatory Commission; and the middle-term bond and short-term financing bond is authorized by the central bank.
}
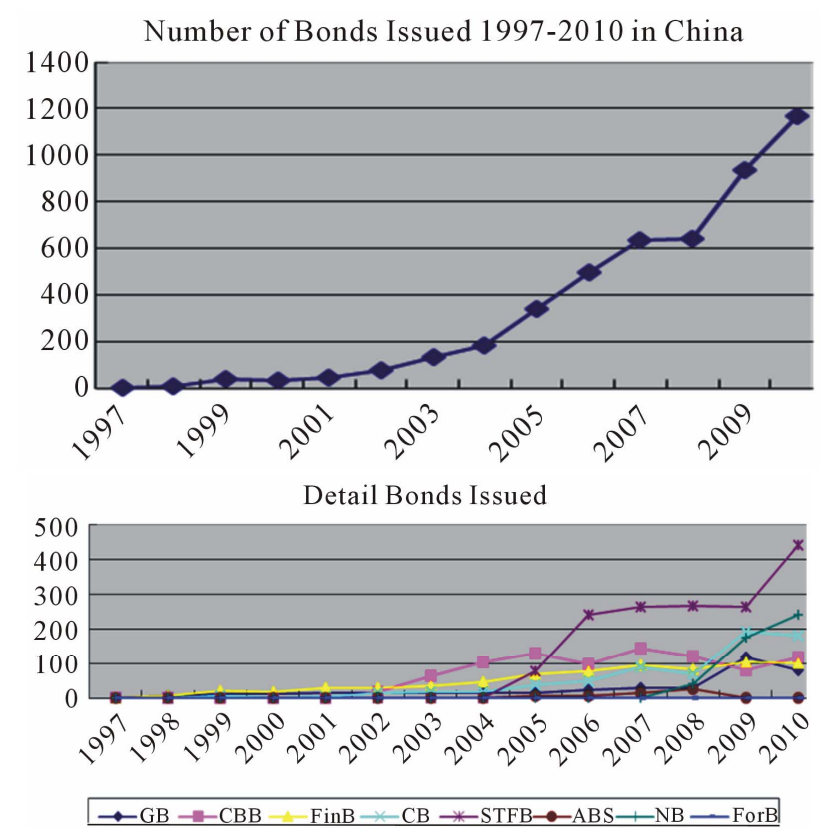

Figure 1. Bonds issued during 1997-2010 in China.

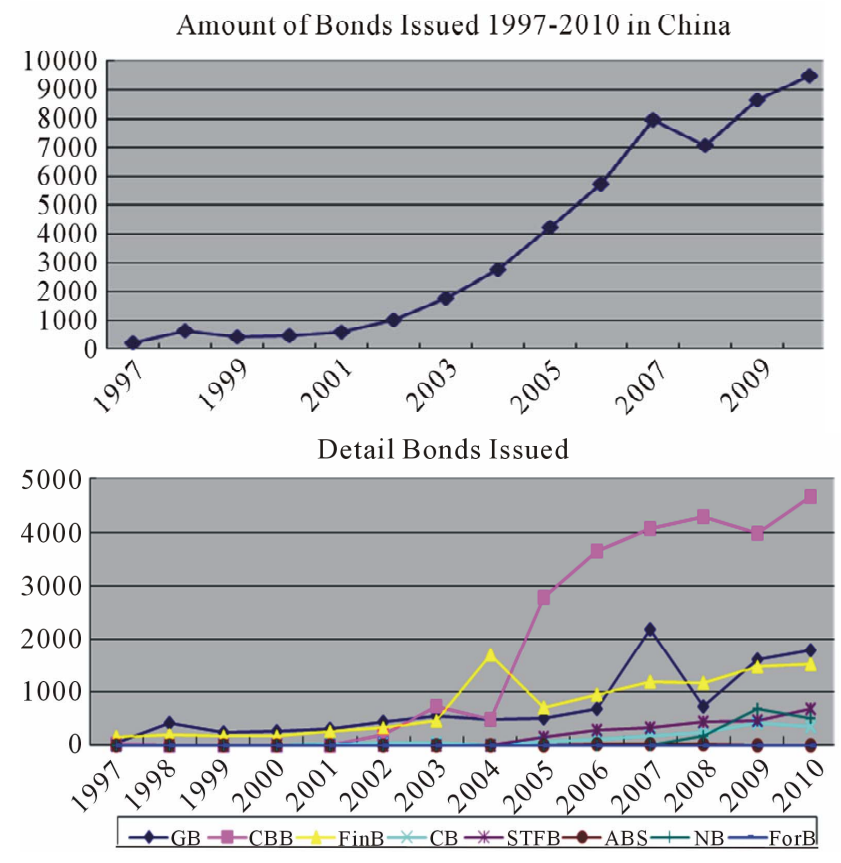

Figure 2. Amounts of bonds issued during 1997-2010 in China.

tional economy and the people's livelihood, as well as reforms in banking industry and the financial innovations. For instance, the bond market supports the banks and financial institutions in asset structure improvement and liquidity management, and it also helps the commercial banks in capital management. It serves as an important platform in financial innovations and strongly supports the reform of rural credit cooperatives. 
Table 1. Number of bonds issued in China in 1997-2010.

\begin{tabular}{cccccccccc}
\hline Year & All & GB & CBB & FinB & CB & STFB & ABS & NB & ForB \\
\hline 97 & 4 & 2 & 1 & 1 & 0 & 0 & 0 & 0 & 0 \\
98 & 12 & 6 & 0 & 6 & 0 & 0 & 0 & 0 & 0 \\
99 & 39 & 13 & 0 & 20 & 6 & 0 & 0 & 0 & 0 \\
00 & 32 & 13 & 0 & 17 & 2 & 0 & 0 & 0 & 0 \\
01 & 50 & 16 & 0 & 29 & 5 & 0 & 0 & 0 & 0 \\
02 & 80 & 16 & 19 & 29 & 16 & 0 & 0 & 0 & 0 \\
03 & 132 & 15 & 63 & 36 & 18 & 0 & 0 & 0 & 0 \\
04 & 186 & 16 & 105 & 46 & 19 & 0 & 0 & 0 & 0 \\
05 & 339 & 15 & 130 & 70 & 37 & 79 & 6 & 0 & 2 \\
06 & 499 & 23 & 98 & 79 & 49 & 242 & 7 & 0 & 1 \\
07 & 636 & 30 & 143 & 95 & 89 & 263 & 16 & 0 & 0 \\
08 & 642 & 29 & 122 & 85 & 71 & 268 & 26 & 41 & 0 \\
09 & 935 & 117 & 81 & 105 & 192 & 263 & 0 & 176 & 1 \\
10 & 1167 & 81 & 119 & 101 & 182 & 442 & 0 & 242 & 0 \\
\hline
\end{tabular}

Note: Data are from http://www.chinabond.com.cn/.

Table 2. Amount of bonds issued in China in 1997-2010 unit: Trillion.

\begin{tabular}{cccccccccc}
\hline Year & Total & GB & CBB & FinB & CB & STFB & ABS & NB & ForB \\
\hline 97 & 208 & 53 & 11 & 143 & 0 & 0 & 0 & 0 & 0 \\
98 & 620 & 427 & 0 & 193 & 0 & 0 & 0 & 0 & 0 \\
99 & 437 & 244 & 0 & 185 & 7 & 0 & 0 & 0 & 0 \\
00 & 441 & 272 & 0 & 164 & 5 & 0 & 0 & 0 & 0 \\
01 & 584 & 308 & 0 & 262 & 14 & 0 & 0 & 0 & 0 \\
02 & 994 & 446 & 193 & 322 & 32 & 0 & 0 & 0 & 0 \\
03 & 1764 & 544 & 722 & 462 & 35 & 0 & 0 & 0 & 0 \\
04 & 2729 & 480 & 480 & 1703 & 2 & 0 & 0 & 0 & 0 \\
05 & 4218 & 504 & 2788 & 711 & 65 & 142 & 4 & 0 & 2 \\
06 & 5709 & 693 & 3657 & 955 & 99 & 292 & 11 & 0 & 1 \\
07 & 7975 & 2188 & 4072 & 1190 & 172 & 334 & 17 & 0 & 0 \\
08 & 7072 & 724 & 4296 & 1178 & 236 & 433 & 30 & 173 & 0 \\
09 & 8647 & 1621 & 3974 & 1474 & 425 & 461 & 0 & 689 & 1 \\
10 & 9508 & 1787 & 4660 & 1526 & 362 & 674 & 0 & 497 & 0 \\
\hline
\end{tabular}

Note: Data are from http://www.chinabond.com.cn/.

However, the bond market in China is small compared with its counterparts abroad and the structure is much simpler, which mostly consists of government bond and financial institution bonds. For the government bond, most are the central government bond while local government bond or city bond is much less, which leads to huge amount of implicit debt and continent debt that are bad for the precaution of fiscal risk and financial risk. Concerning the duration of those bonds, due to the lack of long-term bonds, bond market in China cannot form an effective interest duration structure, which constrains the money policy of the central bank. The bondholders are mostly commercial banks where systematical risk occurs easily. The liquidity is much lower owing to the market separation, lower power of institutional investors, lack of base interest and other market factors heavily constraining the efficiency enhancement and soundness of market system. The regulation efficiency is much lower since the rules and laws remain insufficient, some laws and guidelines are even contradictory, not to mention that some laws and rules established many years ago are outdated. Maybe those factors further restrict the development of the bond market in China.

\subsection{Credit Rating}

As an important step in regulations on bonds, a restrictive, fair and objective credit rating system is used in developed countries. The credit rating usually considers the business risk and financial risk of firms (see [4-6]), insitutional environment (see [7]), and even macro-economy (see $[6,8,9]$ ) that significantly affects the credit rating. Those factors make the credit rating for each bond different from AAA to D (see $[6,8]$ ).

However in China, the regulation on qualification of the bond issuing firms leads to lower demand for the credit rating for a long time. And fierce competition among rating institutions also makes the rating institutions cater for the requirement of bond issuing firms. In 2009, credit rating institutions in China amounted to about 200, of which only 80 were filed in the central bank. And for those filed, most rating institutions are small in size except for Dagong Global Credit Rating Co., Lianhe Credit Rating Co., China Cheng Xin International Credit Rating Co., and Shanghai Brilliance Credit Rating Co. In 2009, the revenues of the biggest 10 credit rating institutions in China account for almost $70 \%$ of the total revenues of the rating industry, and the profits of the most profitable 10 account for $84 \%$ of the total profit of the rating industry including 30 firms that suffer loss (37.5\% of the 80 firms) $)^{2}$.

Moreover, many rating firms are lacking in legal and liability consciences due to the weak regulation system and traditional conventions in China, and the data they collect from firms and other resources are short of verifiability and objectivity. Another problem is that rating firms are inconsistent with each other in rating system

${ }^{2}$ Please refer to Current situation for the credit rating institutions in China, National Business Daily, and November 20, 2009. 
and standards, and many of their staffs are short of necessary knowledge and experience. All those factors make the current credit rating system inefficient in China, exhibiting as no matter how the accounting performance and credit history are; all credit ratings for corporate bonds are AAA. The rating cannot reflect the risk of bond, which makes itself meaningless. Thus the quality of credit rating and the size of rating industry should be improved (see [3]).

\section{STFBs Market in China}

\subsection{The Development}

The issuance of corporate bonds should be approved by National Development and Reform Commission in China, and the processing time as well as the amount issued cannot be determined by the companies. That is why corporate bonds remain somewhat uncertain and elusive. Since the People's Bank of China released Measures for the Administration of Short-term Financing Bills of Securities Companies $^{3}$ on May 24, 2005, short-term financing bonds have been a popular investment choice in the money market. On May 26, 2005, five companies initially issued seven short-term financing bonds of 10.9 billion Yuan in the inter-bank bond market. Due to the low financing cost of short-term financing bonds, enterprises show great enthusiasm for the issuance of shortterm financing bonds (see [10]), and short-term financing bonds give rise to an upsurge among listed companies. This new form of financing could resolve this problem to a certain extent, because STFBs are based on filing system rather than approval system, which means any company with agencies willing to underwrite and investors willing to buy can issue STFBs to achieve capital turnover. Such simple and convenient means of financing undoubtedly becomes the first choice of enterprises, including listed companies. STFBs do not require any guarantee, similar to the commercial acceptance bills and bank loans, reflecting the credit of enterprises. Since currently only enterprises with high credit ratings are entitled to issuing the STFBs which show obvious interest rate differentials compared with other short-term va-

\footnotetext{
${ }^{3}$ On April 9, 2008, the People's Bank of China issued Measures for the Administration of Debt Financing Instruments of Non-financial Enterprises in the Interbank Bond Market, and revoked Measures for the Administration of Short-term Financing Bonds, Regulations of Shortterm Financing Bonds Information Disclosure, and Underwriting Procedures of Short-term Financing Bonds. Thereafter, firms issuing short-term financing bonds should comply with the relevant regulations such as Measures for the Administration of Debt Financing Instruments of Non-financial Enterprises in the Interbank Bond Market, Business Direction of Short-term Financing Bonds of Non-financial Enterprises in the Interbank Bond Market, Issuance Registration Rules of Debt Financing Instruments of Non-financial Enterprises in the Interbank Bond Market, and Intermediary Rules of Debt Financing Instruments of Non-financial Enterprises in the Interbank Bond Market.
}

rieties in money market, the STFBs are also popular among institutions.

Table 3 shows the development data of China's bond market (including STFBs and corporate bonds) by the end of October 2008. STFBs market emerged in 2005, and has developed for nearly 4 years. However, due to the convenience of issuing procedures, STFBs market boasts an issuing frequency almost 4 times that of longterm bond market. Moreover, STFBs market raises funds much more than the corporate bond market does providing enterprises with funds more than twice as much as that of the bond market.

Owing to the convenient procedure of application and low cost of financing, listed companies have issued a large number of STFBs. The statistics of STFBs issued by listed companies during the 4 years are shown in Table $4^{4}$.

STFBs market was initiated in 2005, and the surge of stock market in 2006 and 2007 gave rise to its development. In 2006 and 2007, the scale of STFBs issued by

Table 3. Development and financing condition of china's bond market (including short-term financing bond market and corporate bond market) (2005.1-2008.10).

\begin{tabular}{cccccc}
\hline STFBs Market & 2005 & 2006 & 2007 & 2008 & Total \\
\hline Issuing Times & 79 & 242 & 263 & 231 & 815 \\
$\begin{array}{c}\text { Aggregate Issuance } \\
(100 \text { million })\end{array}$ & 1424 & 2919 & 3349 & 3389 & 11082 \\
$\begin{array}{c}\text { Corporate Bond Market } \\
\quad 2005\end{array}$ & 2006 & 2007 & 2008 & Total \\
$\begin{array}{c}\text { Issuing Times } \\
\text { Aggregate Issuance } \\
(100 \text { million) }\end{array}$ & 37 & 49 & 89 & 56 & 231 \\
\hline
\end{tabular}

Note: data are from http://www.chinabond.com.cn/.

Table 4. STFBs issuance of listed companies (2005.5-d2008. 10).

\begin{tabular}{|c|c|c|c|c|c|}
\hline & 2005 & 2006 & 2007 & 2008 & Total \\
\hline Issuing Times & 27 & 92 & 73 & 49 & 241 \\
\hline \multirow[t]{2}{*}{$\begin{array}{l}\text { Aggregate } \\
\text { Issuance } \\
\text { (100 million) }\end{array}$} & 504 & 1008 & 836 & 610 & 2959 \\
\hline & 3-month & 4-month & 6-month & 9-month & 1-year \\
\hline Issuing Times & 3 & 1 & 8 & 24 & 205 \\
\hline $\begin{array}{l}\text { Aggregate } \\
\text { Issuance } \\
\text { (100 million) }\end{array}$ & 23 & 10 & 477 & 208 & 2240 \\
\hline
\end{tabular}

Note: data are from http://www.chinabond.com.cn/.

${ }^{4}$ Among the 241 short-term financing bonds, 9 of them did not disclose the cost of financing (issuing interest rate), 10 of them were issued before IPO, 3 failed to disclose the rating on the short-term financing bonds. Ultimately there remain 219 sample of short-term financing bonds issuance, among which only 141 have disclosed their ratings on issuing firms. 
listed companies was several times that of 2005. With the stock market's downturn in 2008, bond market was influenced negatively. Among the 241 STFB services, 1 -year financing bonds accounted for about $85 \%$, and 9-month STFBs accounted for $10 \%$. In order to obtain short-term financing, a few enterprises even issued 3month and 4-month STFBs.

\subsection{Advantage of STFB}

First of all, as for enterprises, the introduction of STFB, an innovative form of financing, will be conducive to business expansion and stability and will correspondingly improve the corporate shareholder value. Meanwhile, the low interest rates of STFBs will also help reduce the financial costs of enterprises and thus enhance the net profit, which will further promote the corporate shareholder value.

Secondly, as for banks, currently Chinese enterprises are too dependent on bank loans, and bad debts have caused great losses to some banks. STFBs can change the financing preference of enterprises, because along with the strong expectations of share reform, listed companies are increasingly concerned about the rate of return for shareholders, and equity financing is the most costly of all means of financing. Therefore, the simple and easy bond financing, once appears, will be attractive to listed companies, especially STFBs. Then less refinancing of enterprises will not only ease the credit pressure on commercial banks, but also help to mitigate the pressure of expansion on the secondary market. Once a trend is formed, the exemplary role of STFBs may gradually spread from listed companies to the entire business, and then the commercial banks may not have to undertake the responsibility alone, thus changing the financing structure. That will promote the trend of interest rate marketization, disperse the risk of commercial banks, and enhance the market-oriented reforms of commercial banks.

Thirdly, the growth of the issuing size of STFBs provides available investment tools for the increasing money market funds. The currently active money market funds in the interbank market have amounted to more than 120 billion RMB, while STFBs have a higher investment yield than that of the central bank notes, and the new STFBs can raise the return of money funds. As a result, despite the corresponding tax and legal obstacles, this new form of financing, with money market funds as media and STFBs as carrier, can further improve the financing structure of society, thus promoting the structural optimization of the entire financial market.

In a nutshell, issuing firms, due to their high credit and low risks, are more likely to obtain financing and enjoy lower cost than that of bank loans. The interest rate of STFBs takes the recent short-term interest rates of commercial banks as benchmark, and the low interest rates of issuing will also help enterprises to save financial cost. As for banks, intermediaries and investors, STFBs are more attractive than bank deposits, because issuing firms are companies with higher credit ratings, which suggest relatively lower risk to recover the principal and interest; besides, the STFBs have higher interest rates than that of bank deposits, and is thus more attractive.

In Table 5 we compare the interest rate of STFBs with bank deposit/lending rates over the same period ${ }^{5}$.

In 2005, the average cost of STFBs issued is $2.95 \%$, while the bank deposit rate over the same period is $2.20 \%$. The investors, if investing in STFBs, will enjoy an interest rate $34 \%$ higher than that of bank deposits, which is a great attraction. As for the issuing firms, the cost of STFBs is $47 \%$ lower than the bank lending rate $5.55 \%$ over the same period, also very attractive for the enterprises. Although from 2006 to 2008 the cost of corporate STFBs keeps rising, it is parallel to the change of bank deposit and lending rates over the same period. For investors, the rate of revenue can still be over $40 \%$ higher than the bank deposit rate; and for issuing firms, financing through STFBs still holds significant edges, and the cost is at least $23 \%$ lower than the bank lending rate over the same period, though the gap is narrowing. The decrease in profit margin occurs, probably because STFBs have such large profit margins, and issuing firms have kept increasing.

In Table 6, STFBs are broken down by different terms, and a comparison between the cost of STFBs and bank lending rate over the same period ${ }^{6}$ is carried out to indicate the attraction to issuing firms. In fact, STFBs, no matter 3-month, 6-month or 1-year, can save the cost significantly for issuing firms. With the expected rising inflation and the central bank's tightening of monetary policy, bank lending rates will increase, and so do corporate financing costs. STFBs then become a superior means of financing.

\subsection{Rating of STFB}

In the United States, all publicly traded bonds have gone through one or more rating agencies whose role is to measure the default risk and bankruptcy risk of the bonds (see [11]). In Measures for the Administration of Shortterm Financing Bills, the People's Bank of China stipulated that "Financing bonds issued by enterprises shall be

\footnotetext{
${ }^{5}$ Bank deposit rates over the same period mean the deposit rates of bank for the same term if the same amount of money for short-term financing bonds is deposited in the bank at the time of bond issuance; bank lending rates over the same period refer to the lending rates of bank for the same term if the same amount of money for short-term financing bonds is borrowed from the bank at the time of bond issuance.

${ }^{6}$ Bank lending rates over the same period refer to the lending rates of bank for the same term if the same amount of money for short-term financing bonds is borrowed from the bank at the time of bond issuance.
} 
Table 5. Comparison between interest rate of stfbs and bank deposit/lending rates over the same period.

\begin{tabular}{|c|c|c|c|c|c|}
\hline & $\begin{array}{l}\text { Interest Rate } \\
\text { of STFBs }\end{array}$ & $\begin{array}{l}\text { Bank Deposit Rate } \\
\text { over the Same Period }\end{array}$ & $\begin{array}{l}\text { Bank Lending Rate over } \\
\text { the Same Period }\end{array}$ & $\begin{array}{c}\text { Interest Rate of STFB is higher than } \\
\text { Bank Deposit Rate by }\end{array}$ & $\begin{array}{c}\text { Interest Rate of STFB is lower than } \\
\text { Bank Lending Rate by }\end{array}$ \\
\hline 2005 & 2.95 & 2.19 & 5.55 & $34 \%$ & $-47 \%$ \\
\hline 2006 & 3.61 & 2.29 & 5.83 & $58 \%$ & $-38 \%$ \\
\hline 2007 & 4.43 & 3.15 & 6.68 & $41 \%$ & $-34 \%$ \\
\hline 2008 & 5.75 & 4.11 & 7.43 & $40 \%$ & $-23 \%$ \\
\hline Total & 4.20 & 2.89 & 6.37 & $45 \%$ & $-34 \%$ \\
\hline
\end{tabular}

Table 6. Comparison between interest rate of stfbs with different terms and bank lending rate over the same period.

\begin{tabular}{|c|c|c|c|c|}
\hline \multicolumn{5}{|c|}{ Interest Rate of STFBs } \\
\hline Term & 2005 & 2006 & 2007 & 2008 \\
\hline 3-month & NA & 2.8935 & 4.0600 & NA \\
\hline 4-month & NA & NA & NA & 4.600 \\
\hline 6-month & 2.5638 & 3.0670 & $3.7600^{\mathrm{a}}$ & NA \\
\hline 9-month & 2.7858 & 3.4266 & 4.3376 & 5.3800 \\
\hline \multirow[t]{2}{*}{ 1-year } & 3.0454 & 3.7048 & 4.4735 & 5.7908 \\
\hline & \multicolumn{4}{|c|}{ Bank Lending Rate over the Same Period } \\
\hline Term & 2005 & 2006 & 2007 & 2008 \\
\hline 3-month & NA & 5.400 & 6.4800 & NA \\
\hline 4-month & NA & NA & NA & 6.5700 \\
\hline 6-month & 5.2200 & 5.4900 & $6.1650^{\mathrm{a}}$ & NA \\
\hline 9-month & 5.2200 & 5.8009 & 6.6060 & 7.4700 \\
\hline 1 -year & 5.5800 & 5.8782 & 6.7071 & 7.4558 \\
\hline
\end{tabular}

a: In 2007 the interest rate of 6-month STFBs and the bank lending rate over the same period are both lower than those of 3-month bonds, because in 2007 the central bank adjusted the interest rate for several times, and 6-month STFBs were mostly issued before the sharp readjustment of interest rates.

registered in the industrial and commercial authorities in China and shall go through credit rating by qualified bond rating agencies, and the rating result shall be open to the inter-bank bond market".

In theory, the rating on firm of STFBs is the evaluation of the overall credit condition of issuing firms, and the results reveal the basic credit rating of debt issuers; and the rating on bond is the rating for particular bonds, and the results reveal the credit rating of the specific bond. In practice, the credit ratings of bond issue and its issuing firm are not exactly the same. The credit rating of the issuer reflects the capacity of issuer to repay senior debt or unsecured debt; while bonds of different types are different in clauses, which leads to different default loss rate, so the credit ratings of specific bond issue often deviate from that of the issuing firm. For the bonds with external credit enhancement terms such as guarantee which means that bondholders have the joint right to recover against the guarantor, though the default pro- bability is not reduced, the bondholders tend to have a lower default loss rate, and their protection from loss is strengthened, so the rating on bond is usually higher than its rating on issuer.

Currently in China, there are five recognized bond rating agencies, namely CCXI, Shanghai Far East, Dagong, Lianhe, and Shanghai Brilliance, also known as "Big Five". However, due to the lack of scientific definition on credit risks of bonds, the current credit rating system remains flawed (see [2]). Consequently, the rating agencies give all STFBs a credit rating of A-1, and almost no difference exists ${ }^{7}$. This rating system or its rating results do not reflect the information that bond rating should provide, instead they increase the corporate issuing costs. Investors are not able to obtain effective

\footnotetext{
${ }^{7}$ Among 241 STFBs, 33 of them are rated A-1+, of which most are rated in 2005 and 2006. This is because of the changes in credit rating system and it indicates no difference from A-1. So we classify A-1+ and A-1 into the same class.
} 
information associated with investment risks from the results of bond rating. The quality and scale of bond market rating service need to be improved, while the industry growth is restrained by a great many limits (see [3]). Of course, for lack of reference object, we cannot completely deny the existing ratings.

However, when firms issue STFBs, not only credit ratings on the bonds and issuer are carried out, but also track rating on the bond issue and issuers. Although credit ratings of STFBs lack comparability and can hardly determine the associated risks, the credit rating of issuing firms can effectively reveal the credit risk of STFBs (see [12]).

As the information is incomplete, we only find 142 ratings on issuing firms of STFBs, as shown in Table 7.

Although almost all the STFBs are A-1 rated which indicates the highest level of credit rating, and there is hardly any difference, the rating on the issuing firm leads to quite different results. Table 7 shows that only 13 STFBs have their issuers rated AAA, the majority of firms are rated AA, and the rest are A-rated.

As for institutional investors or banks, undeniably, the above rating system of STFBs does not provide any information. The same rating for listed companies issuing STFBs means the same risk. In accordance with rules of the international bond market, bonds of the same term shall have the same rate of return, which means the costs of STFBs shall also be the same. However, even if bonds of the same term are rated the same, their rates of return are quite different. Table 8 will categorize the ratings into AAA, AA and A, and compare the relationship between different ratings of STFBs and their costs.

Of all the 142 STFBs that have disclosed the credit rating of issuers, the average financing cost of AAA-

Table 7. Rating results on issuing firms of STFBs.

\begin{tabular}{cccccccccc}
\hline Credit Rating & AAA & AAA- & AA+ & AA & AA- A+ A A- & Total \\
\hline All & 2 & 11 & 33 & 37 & 25 & 21 & 2 & 11 & 142 \\
1-year Term & 2 & 10 & 31 & 33 & 22 & 15 & 2 & 6 & 121
\end{tabular}

Note: Huaneng Power International's STFBs are measured by Standard \& Poor's rating levels (BBB), which are different from domestic rating agencies. So we just compare the results from domestic rating agencies. Data are from http://www.chinabond.com.cn/.

Table 8. Rating on issuing firms of STFBs and financing costs.

\begin{tabular}{|c|c|c|c|c|c|c|c|}
\hline & $\mathrm{N}$ & AAA & AA & A & $\begin{array}{l}\text { AAA is } \\
\text { lower than } \\
\text { AA by }\end{array}$ & $\begin{array}{c}\mathrm{AA} \text { is } \\
\text { lower } \\
\text { than } \mathrm{A} \text { by }\end{array}$ & $\begin{array}{l}\text { AAA is } \\
\text { lower than } \\
\text { A by }\end{array}$ \\
\hline All & 142 & 3.54 & 4.53 & 4.87 & $28 \%$ & $8 \%$ & $36 \%$ \\
\hline $\begin{array}{c}\text { 1-year } \\
\text { term }\end{array}$ & 121 & 3.63 & 4.66 & 4.95 & $28 \%$ & $6 \%$ & $34 \%$ \\
\hline
\end{tabular}

Note: data are from http://www.chinabond.com.cn/. rated (including $\mathrm{AAA}+$ and $\mathrm{AAA}-$ ) bonds is $3.55 \%$, the average interest rate of AA-rated (including $\mathrm{AA}+, \mathrm{AA}$ and AA-) bonds is $4.53 \%$, and that of A-rated (including $\mathrm{A}^{+}, \mathrm{A}$ and $\left.\mathrm{A}-\right)$ is $4.88 \%$, showing a rising tendency. Lower credit rating appears to result in higher financing costs. The financial edge for AAA-rated issuing firms seems more apparent as the cost of financing for AAArated issuing firms is $28 \%$ lower than that of the AArated and is even $37 \%$ lower than that of the A-rated, while the cost of financing for AA-rated issuing firms is only $8 \%$ lower than that of the A-rated. In order to exclude the impact of different terms of STFBs, we specifically make a comparison among 121 one-year STFBs and the results remain consistent, AAA-rated issuing firms have the lowest cost of financing, and its financing edge is the most obvious compared with issuing firms of lower credit ratings.

\section{Usefulness of Credit Rating in China}

\subsection{Credit Rating and Financing Cost}

Corporate STFBs, by nature, are similar to the comercial financing bills in foreign financial markets. From the perspective of pricing, the rate of return for STFBs should generally be based on the rate of return for national bonds of the same term, with comprehensive consideration to the factors such as the credit rating of issuing firms and the liquidity of bonds; that is, rate of return for short-term financing bonds $=$ rate of return for national bonds of the same term + credit spread + liquidity premium + tax differentials. However, as short-term national bonds issued in our country are non-institutional, and due to the long-term absence of the corresponding interest rate curve, it is difficult to reasonably price the STFBs.

For the lack of empirical researches on the rate of return for STFBs, Zhang and Wang [13] discuss the pricing of STFBs based on the option pricing theory, and they believe that currently Black-Scholdes model and Metro model are applicable to the pricing of STFBs in China. Zou and Liu [14] use Metro model market to study the rate of return for STFBs market in China, and they find that the risk-free rate of return significantly affects the yield of STFBs. Li and Dai [15] carry out an empirical analysis on the interest rate of STFBs issued in the inter-bank market from 2005 to December of 2006, and they find that corporate ownership, size of issuing, benchmark interest rates and the industrial indicators significantly affect the rate of return for STFBs, while underwriter reputation, short-term and long-term solvency are uncorrelated with the yield of STFBs. All these studies, however, have ignored the impact of credit rating on the corporate cost of financing. In theory, the most important role of credit rating for the issuers is to reduce 
financing costs, which is mainly manifested by the lower interest rates of issued bonds. Overseas studies have found that bonds with different interest rates, according to their different ratings, show a certain interest rate differential (credit spread). The bond ratings are closely correlated with the financing costs, so it is particularly crucial to obtain better ratings (see [16]).

In foreign countries, better credit rating tends to lower the risk of enterprises, and thus lower the cost of financing. In China's bond market, however, almost all the long-term bonds, including debenture and enterprise bonds, are rated AA or above, which shows no difference. The ratings of STFBs are mostly A-1 which is the highest for STFBs. For investors, the above rating results can be a signal of risk, but they cannot distinguish risks of STFBs among different companies. Credit rating system does not seem to provide sufficient information for investors. The credit ratings of STFBs cannot help to distinguish risks and revenues of different financing bonds, but the inherent risks of firms can still affect the earnings of STFBs. Investors can rely on the ratings on issuing firms to further reduce risks or to pursue high returns.

The interest rate of STFBs takes the recent short-term lending interest rates of commercial banks as benchmark, so the benchmark interest rate of the same term is an important factor. Liquidity also greatly affects the corporate cost of financing, especially in the market of extreme circumstances such as the steep rising of stock market or liquidity shortage of the entire market. Moreover, the size of financing will also affect the market expectations, particularly in terms of banks holding large deposits, STFBs with low risk and fixed yield that can be taken as the investment portfolio for money market funds. Meanwhile, the inherent profitability, liabilities, assets and cash flow, and even ownership structure of issuing firms may affect their financing costs.

If the rating of STFBs is aimed for the qualification for issuance, then the uniform ratings can hardly deliver effective information to investors. On the contrary, Table 6 shows that the rating on issuing firms and the cost of STFBs are closely linked. Therefore, can the rating on issuing firms serve as an alternative to the credit rating of STFBs? To illustrate the impact of credit rating, we use credit rating on issuing firms to test, and the results are shown in Table 9.

Model 1 controls for the duration of STFBs, the benchmark lending interest rate over the same term and the impact of issuing size on financing costs, which are measured as the interest spread as Zhang [17] that the rate of bond minus the counterparty deposit interest rate, coefficient of Credit is negative significantly at 0.01 level, indicating that credit ratings can reduce corporate financing costs. Moreover, we find that the duration, benchmark interest rate and issuing size of STFBs have a very significant impact on the interest rates of STFBs. The longer the term of financing bonds is, the lower the financing costs of enterprises tend to be; which may be caused by liquidity, because the greater demand for liquidity results in greater financial pressure and higher cost.

Model 2 controls for other fundamental characteristics. Still the coefficient for Credit is significantly negatively related with the financing cost. And the duration is also negatively related with financing cost, showing the liquidity premium. However, issuing size now has no influence after controlling for fundamentals, which means the cost is not due to the financing size. The size, leverage and profitability of issuing firm have no influence on financing cost, which may be due to that their influence has already been reflected on credit rating. While the coefficient of cash flow is significantly negative because investors expect fewer problems to the corporate liquidity, which also means the cash flow from operation may be not accounted when credit is rated.

In order to further verify the conclusions of Table 9, Table 10 carries out a robustness test ${ }^{8}$ on the above results. The first two columns are yearly tests and the final column uses 1-year STFBs as samples for further test.

Yearly regression results show that rating on issuing firm of short-term financing bond is negatively correlated with its cost of financing, at least at the significance level of 0.05 , which supports the conclusions of Table 8 .

The regression of 1-year STFBs samples still shows that credit rating is negatively correlated with financing costs at the significance level of 0.01 , further supporting the results of Table 9 .

\subsection{Credit Rating and Risk}

Results in Tables $\mathbf{9}$ and $\mathbf{1 0}$ show that rating on issuing firm of short-term financing is closely related with the cost of short-term bonds, meaning that the rating on issuing firm can substitute the rating on bonds for risk evaluation. This substitution is mainly due to the fundamentals of issuing firms, reflecting their payment ability and default risks. Table $\mathbf{1 1}$ shows the relation between ratings on issuing firms and their fundamental aspects.

Based on model 4 , model 5 divides the leverage into short-term and long-term in order to investigate the influence of debt structure on the rating of issuing firms. And model 6 further controls the effect of ownership structure.

Coefficients for Size are all significantly positive in three models, consistent with Chen and Guo [11] that scale effect has significantly influence on firms' rating.

\footnotetext{
${ }^{8}$ To maintain the freedom of regression models, in robustness test we omit the impacts of fundamental factors and equity characteristics. Inclusion of these variables will not influence the regression results basically.
} 
Table 9. Bond rating and financing cost Spread $=\alpha+\beta_{1}$ Credit $+\beta_{2}$ Baserate $+\beta_{3}$ Duration $+\beta_{4}$ Amount $+\beta_{5}$ Size $+\beta_{6}$ Lev $+\beta_{7}$ CFO $+\beta_{8} R O E+\beta_{9}$ State $+\beta_{10} V+\beta_{11} C V+\Sigma I n d s+\varepsilon$.

\begin{tabular}{|c|c|c|c|c|}
\hline Variables & Expsign & Model 1 & Model 2 & Model 3 \\
\hline \multirow[t]{2}{*}{ Credit } & - & $-0.170^{* * *}$ & $-0.138^{* * *}$ & $-0.135^{* * *}$ \\
\hline & & $(-4.06)$ & $(-2.75)$ & $(-2.67)$ \\
\hline \multirow[t]{2}{*}{ Baserate } & + & $0.421^{* * *}$ & $0.395^{* * *}$ & $0.380^{* * *}$ \\
\hline & & $(5.66)$ & $(5.27)$ & $(4.94)$ \\
\hline \multirow[t]{2}{*}{ Duration } & - & $-0.820^{* * *}$ & $-0.953^{* * *}$ & $-0.985^{* * *}$ \\
\hline & & $(-2.63)$ & $(-3.00)$ & $(-3.08)$ \\
\hline \multirow[t]{2}{*}{ Amount } & $?$ & $-0.152^{* *}$ & -0.107 & -0.121 \\
\hline & & $(-2.01)$ & $(-1.12)$ & $(-1.25)$ \\
\hline \multirow[t]{2}{*}{ Size } & - & & -0.066 & -0.059 \\
\hline & & & $(-0.85)$ & $(-0.76)$ \\
\hline \multirow[t]{2}{*}{ Lev } & + & & 0.468 & 0.436 \\
\hline & & & (1.19) & (1.09) \\
\hline \multirow[t]{2}{*}{$\mathrm{CFO}$} & - & & $-1.705^{* *}$ & $-1.947^{* *}$ \\
\hline & & & $(-2.11)$ & $(-2.36)$ \\
\hline \multirow[t]{2}{*}{ ROE } & - & & 0.495 & 0.650 \\
\hline & & & $(0.57)$ & $(0.74)$ \\
\hline \multirow[t]{2}{*}{ State } & $?$ & & & 0.002 \\
\hline & & & & $(0.02)$ \\
\hline \multirow[t]{2}{*}{$\mathrm{V}$} & $?$ & & & 0.059 \\
\hline & & & & $(0.18)$ \\
\hline \multirow[t]{2}{*}{$\mathrm{CV}$} & - & & & -0.315 \\
\hline & & & & $(-1.37)$ \\
\hline Inds & & Control & Control & Control \\
\hline $\mathrm{N}$ & & 142 & 142 & 142 \\
\hline $\mathrm{R}^{2}$ & & 0.460 & 0.490 & 0.502 \\
\hline
\end{tabular}

Note: The dependent variable (Spread) is the issuing interest rate of STFBs minus the counterparty deposit interest rate; Credit means the credit ratings ranging from AAA+ (highest) to A- (lowest), which is assigned from 8 to 1; Baserate is the benchmark interest rate, the same with bank lending rates over the same period $^{9}$; Duration indicates the term for STFBs, in years; Amount is the natural logarithm for the total amount of STFBs; Size is the natural logarithm for total assets at the beginning; Lev indicates the asset-liability ratio at the beginning; ROE is the net rate of return in the previous term; State is a sub-variable, 1 for a listed company ultimately controlled by country, and otherwise 0 ; $\mathrm{V}$ means the control power of ultimate controller on listed companies (in the proportion of voting rights); $\mathrm{CV}$ is for ratio of the right in cash flow earnings to controlling right of the ultimate controller; Inds is for the industrial dummy variables, 12 industries (excluding the financial sector) are characterized by 11 dummy variables. The white-t in brackets deals with heteroscedasticity in the regression model. ***,** and * indicates the significance at the level of $0.01,0.05$ and 0.10 , respectively.

And both the short-term leverage and long-term leverage are key determinants for the firm rating, inconsistent with

\footnotetext{
${ }^{9}$ Jiang [18] study China's market interest rate system from the perspective of asset pricing and find that deposit rate is more suitable to serve as the benchmark for other assets pricing, and should be the benchmark interest rates for our current financial market. Therefore, we chose bank deposit rates over the same period as benchmark interest rate. In the robustness test, we also use bank lending rates over the same period as benchmark interest rate.
}

Chen and Guo [11] that long-term leverage does not affect the rating. Coefficients for ROE are positive and significant at 0.10 levels which mean that profitability is also a key determinant for rating. However, the cash flow does not significantly affect the rating, nor do the ownership structure variables. The scale effect, leverage and profitability can explain the rating on issuing firms for about 75 percent. 
Table 10. Robustness test Spread $=\alpha+\beta_{1}$ Credit $+\beta_{2}$ Baserate $+\beta_{3}$ Duration $+\beta_{4}$ Amount $+\Sigma$ Inds $+\varepsilon$.

\begin{tabular}{ccccc}
\hline Variables & Expsign & $2005-2006$ & $2007-2008$ & 1 -year Term \\
\hline Credit & - & -0.083 & $-0.233^{* * *}$ & $-0.177^{* * *}$ \\
& & $(-1.48)$ & $(-4.55)$ & $(-3.66)$ \\
Baserate & + & $0.941^{* * *}$ & $0.698^{* * *}$ & $0.421^{* * *}$ \\
& & $(4.22)$ & $(6.26)$ & $(5.01)$ \\
Duration & - & -0.625 & $-1.088^{* *}$ & \\
& & $(-1.66)$ & $(-2.51)$ & \\
Amount & - & -0.117 & -0.129 & $-0.217^{* *}$ \\
& & $(-1.60)$ & $(-1.22)$ & $(-2.04)$ \\
Inds & & Control & Control & Control \\
$\mathrm{N}$ & & 37 & 105 & 121 \\
$\mathrm{R}^{2}$ & & 0.703 & 0.579 & 0.459 \\
\hline
\end{tabular}

Note: Same as above.

In all, firms with lager size, lower leverage and higher profitability are accorded with higher credit, reflecting their lower default risk. Therefore, even if the rating on short-term bond cannot reflect the differences among bonds, the rating on issuing firm of short-term financing can play this role, substituting for the rating on bonds to reflect risk.

\section{Conclusions}

Nowadays in China, financing still relies heavily on bank loans while the direct financing from bond and equity market remains small. Fortunately, in recent years Chinese government has highly emphasized the development of bond market where credit rating is very important. However at present in China's bond market, almost all bonds are rated the highest ${ }^{10}$.

Take Short-Term Financing Bond (STFB) as an example, for investors the rating should be a signal of risk, but as a matter of fact they cannot distinguish risks among different companies. Credit rating tends to lose its function of measuring default risk in the market. While investors can rely on the ratings on issuing firms to further reduce risks or to pursue high returns, which means credit rating for STFBs should be further detailed, as the uniform ratings cannot provide effective information for investors. To address the problem that the ratings on issuing firms of STFBs cannot effectively reveal credit risk, we should gradually diversify the results of credit rating

\footnotetext{
${ }^{10}$ Long-term bonds are AAA rated, and only a few are AA-rated; short-term financing bonds are rated A-1.
}

Table 11. Rating on issuing firm of short-term financing and firms' fundamental Spread $=\alpha+\beta_{1}$ Size $+\beta_{2} L e v+\beta_{3}$ CFO $+\beta_{4} R O E+\beta_{\mathrm{i}} O$ wnership $+\Sigma$ Inds $+\varepsilon$.

\begin{tabular}{|c|c|c|c|c|}
\hline \multicolumn{2}{|c|}{ Variables } & \multirow{2}{*}{$\begin{array}{c}\text { Model } 4 \\
0.9727 \\
(18.28)^{* * *}\end{array}$} & \multirow{2}{*}{$\begin{array}{c}\text { Model } 5 \\
1.0108 \\
(14.44)^{* * *}\end{array}$} & \multirow{2}{*}{$\begin{array}{c}\text { Model } 6 \\
0.9738 \\
(11.71)^{* * *}\end{array}$} \\
\hline Scale & Size & & & \\
\hline & Lev & $\begin{array}{l}-3.5646 \\
(-4.43)^{* * *}\end{array}$ & & \\
\hline \multirow[t]{2}{*}{$\begin{array}{c}\text { Default } \\
\text { Risk }\end{array}$} & Shortlev & & $\begin{array}{l}-3.1669 \\
(-3.76)^{* * *}\end{array}$ & $\begin{array}{l}-2.8539 \\
(-3.33)^{* * *}\end{array}$ \\
\hline & LongLev & & $\begin{array}{l}-4.6560 \\
(-3.70)^{* * *}\end{array}$ & $\begin{array}{l}-4.3415 \\
(-3.55)^{* * *}\end{array}$ \\
\hline Profitability & ROE & $\begin{array}{l}3.1403 \\
(1.98)^{*}\end{array}$ & $\begin{array}{l}2.9820 \\
(1.86)^{*}\end{array}$ & $\begin{array}{l}2.8483 \\
(1.76)^{*}\end{array}$ \\
\hline \multirow[t]{2}{*}{$\begin{array}{l}\text { Payment } \\
\text { Ability }\end{array}$} & $\mathrm{CFO}$ & $\begin{array}{c}-0.5722 \\
(-0.37)\end{array}$ & $\begin{array}{c}-0.3173 \\
(-0.21)\end{array}$ & $\begin{array}{c}-0.1610 \\
(-0.10)\end{array}$ \\
\hline & State & & & $\begin{array}{c}-0.0857 \\
(-0.36)\end{array}$ \\
\hline \multirow[t]{5}{*}{$\begin{array}{l}\text { Ownership } \\
\text { Structure }\end{array}$} & $\mathrm{V}$ & & & $\begin{array}{c}0.8299 \\
(1.39)\end{array}$ \\
\hline & $\mathrm{CV}$ & & & $\begin{array}{l}0.3355 \\
(0.77)\end{array}$ \\
\hline & Inds & Control & Control & Control \\
\hline & $\mathrm{N}$ & 142 & 142 & 142 \\
\hline & $\mathrm{R}^{2}$ & 0.7473 & 0.7517 & 0.7576 \\
\hline
\end{tabular}

Note: the dependent variable Credit means the credit ratings ranging from $\mathrm{AAA}+$ (highest) to A- (lowest), which is assigned from 8 to 1; Size is the natural log of assets at year beginning; Lev is the total leverage at year beginning; Shortlev is the short-term leverage at year beginning and Longlev is the long-term leverage; ROE is the return on equity for the previous year; CFO is the cash flow from operation for the previous year divided by total assets; State is a dummy variable, 1 indicates the ultimate shareholder is government and 0 otherwise; $\mathrm{V}$ is the control right of ultimate shareholders, and CV is the divergence of cash flow right and control right; Inds is for the industrial dummy variables, 12 industries (excluding the financial sector) are characterized by 11 dummy variables. The white-t in brackets deals with heteroscedasticity in the regression model. ***,** and * indicates the significance at the level of $0.01,0.05$ and 0.10 , respectively.

on STFBs and increase its levels of discrimination, so that it can better reveal the credit risks of the STFBs.

This paper provides more information for foreign and domestic investors about the bond market and the credit rating in China, and gives answer to the question about efficiency of bond rating in China. It provides some evidence for the reliability of rating in China though it is still in its early stage. Results indicate that credit ratings in China are important for investors in risk judgment and can significantly influence the financing cost of firms issuing bonds. In order to stimulate the development of bonds market in China, authorities should pay more attention in credit rating.

The bond market in China is small compared with its counterparts abroad and the structure is much simpler, which cannot provide powerful financing for all kinds of 
investors and firms. To promote the development of bond market, not only some financial reforms should be launched, but also the credit rating should be enhanced in terms of the rating diversification and efficiency in disclosing the risk.

\section{REFERENCES}

[1] X. L. Wu, "The Development and Openness of Bond Market in China," China Finance, Vol. 632, No. 2, 2008, pp. 10-12.

[2] F. Q. Cao, "Developing Strategy of China's Capital Market," Peking University Press, Peking, 2003.

[3] Z. W. Ou and W. Xiao, "Plan of Credit Rating System in China," Shanghai University of Finance and Economics Press, Shanghai, 2005.

[4] E. I. Altman, "Predicting Railroad Bankruptcies in America," Bell Journal of Economics, Vol. 4, No. 1, 1973, pp. 184-211. doi: $10.2307 / 3003144$

[5] R. Merton, "On the Pricing of Corporate Debt: The risk Structure of Interest Rates," The Journal of Finance, Vol. 29, No. 2, 1974, pp. 449-470.

[6] J. D. Amato and C. H. Furfine, "Are Credit Ratings Procyclical?” Journal of Banking \& Finance, Vol. 28, No. 11, 2004, pp. 2641-2677. doi:10.1016/j.jbankfin.2004.06.005

[7] A. W. Butler and L. Fauver, "Institutional Environment and Sovereign Credit Ratings," Financial Management, Vol. 35, No. 3, 2006, pp. 53-79. doi:10.1111/j.1755-053X.2006.tb00147.x

[8] E. I. Altman and H. A. Rijken, "How Rating Agencies Achieve Rating Stability?" Journal of Banking \& Finance, Vol. 28, No. 11, 2004, pp. 2679-2714. doi:10.1016/j.jbankfin.2004.06.006
[9] K. Carling, T. Jacobson, J. Linde and K. Roszbach, "Corporate Credit Risk Modeling and the Macroeconomy," Journal of Banking \& Finance, Vol. 31, No. 3, 2007, pp. 845-868. doi:10.1016/j.jbankfin.2006.06.012

[10] J. Gao, "How to Price Short-term Financing Bonds?" Cnstock.com-Shanghai Securities News, 11 August 2005.

[11] C. Chen and Z. M. Guo, "China's Corporate Bond Financing, Financial Risk and Bond Rating," Contemporary Finance \& Economics, Vol. 279, No. 2, 2008, pp. 39-48.

[12] H. L. Ju, "Short-Term Financing Bond Rating: Can Credit Rating Replace Debt Rating?" Shanghai Securities News, 31 October 2008.

[13] G. M. Zhang and R. Wang, "Study on the Pricing of Short-Term Financing Bonds," Finance and Economy, Vol. 16, No. 8, 2006, pp. 11-114.

[14] P. Zou and Y. Liu, "Study on the Pricing of China's Corporate Short-Term Financing Bonds," Contemporary Finance \& Economics, Vol. 152, No. 4, 2008, pp. 66-70.

[15] H. Li and H. Dai, "Factors to Affect the Issuing Prices of Short-Term Financing Bonds," Finance Forum, Vol. 142, No. 10, 2008, pp. 59-63.

[16] H. J. Dong and W. Liu, "Empirical Analysis of the Relationship between Bond Rating and Funding Costs," Studies of International Finance, Vol. 119, No. 10, 1993, pp. 10-13.

[17] J. Zhang, "The Contracting Benefits of Accounting Conservatism to Lenders and Borrowers," Journal of Accounting and Economics, Vol. 45, No. 1, 2008, pp. 27-54. doi:10.1016/j.jacceco.2007.06.002

[18] X. F. Jiang, H. Wang and Y. D. Shi, "Options of Benchmark Interest Rates in China's Financial Market," Journal of Financial Research, Vol. 340, No. 10, 2008, pp. 22-36. 